\begin{tabular}{|c|c|c|}
\hline (4) Divanika & $\begin{array}{c}\text { Dinamika Journal, Vol. } 1 \text { No.1, } 2019 \\
\text { Journal Homepage }: \underline{\text { http://jurnal.lppm.unsoed.ac.id/ojs/index.php/dinamika }}\end{array}$ & $\left(\frac{1963 *}{* 2}\right.$ \\
\hline
\end{tabular}

\title{
DIVERSIVIKASI HASIL OLAHAN IKAN LELE DI DESA KALIWANGI, KECAMATAN PURWOJATI, KABUPATEN BANYUMAS
}

\author{
Diana Retna Utarini Suci Rahayu ${ }^{1}$, Agatha Sih Piranti ${ }^{1}$ dan Idha Sihwaningrum ${ }^{2}$ \\ ${ }^{1)}$ Fakultas Biologi, Universitas Jenderal Soedirman, Purwokerto \\ ${ }^{2)}$ Jurusan Matematika, Fakultas Matematik dan Ilmu Pengetahuan Alam (MIPA), Universitas \\ Jenderal Soedirman, Purwokerto \\ *Corresponding author $:$ dianaretna.01@gmail.com
}

Received 20 May 2019; Accepted 4 July 2019; Available online 6 July 2019

\begin{abstract}
Abstrak
Ketahanan pangan merupakan salah satu faktor penentu kesejahteraan masyarakat khususnya di pedesaan. Upaya untuk mencapai kondisi tersebut perlu adanya kerjasama antar berbagai elemen, salah satunya peran perguruan tinggi melalui kegiatan pengabdian masyarakat. IPTEKS tentang diversifikasi hasil olahan ikan lele, telah dilakukan di Desa Kaliwangi Kecamatan Purwojati Kabupaten Banyumas. Kegiatan tersebut bertujuan untuk meningkatkan pengetahuan dan kemampuan ibu-ibu anggota PKK dan para remaja putri Desa Kaliwangi dalam mengolah makanan yang bersumber dari bahan baku yang sama menjadi beberapa tampilan yang berbeda; memberikan ketrampilan dalam penanganan pasca panen, khususnya pengolahan ikan lele menjadi bahan olahan siap saji yang sehat, bergizi, praktis serta ekonomis; memberikan ketrampilan kreatif pada ibu-ibu anggota PKK dan para remaja putri dalam membuat nugget dan kaki naga lele dan, memberikan ketrampilan dalam pengemasan produk olahan ikan (khususnya pembuatan nugget dan kaki naga). Metode yang digunakan meliputi pembekalan materi melalui penyuluhan/ceramah, praktek dan demostrasi plot (demplot), selanjutnya dilakukan monitoring dan evaluasi. Selama kegiatan praktek dilakukan pendampingan untuk membantu khalayak sasaran menghasilkan produk yang bagus. Hasil evaluasi menunjukkan adanya peningkatan pengetahuan, pemahaman dan ketrampilan di dalam mengolah ikan lele sebagai produk olahan baru berupa nugget dan kaki naga yang disukai dan bermanfaat bagi kesehatan serta dapat digunakan sebagai salah satu peluang usaha.
\end{abstract}

Kata kunci: Desa Kaliwangi, diversivikasi pangan, ikan lele, nugget, pengolahan 


\begin{abstract}
Food security is one of the determinants of people's welfare, especially in rural areas. Efforts to achieve these conditions need cooperation between various elements, one of which is the role of universities through community service activities. Science and technology about diversification of processed catfish products has been carried out in Kaliwangi Village, Purwojati District, Banyumas Regency. The activity aims to increase the knowledge and abilities of PKK member mothers and young women in Kaliwangi Village in processing food sourced from the same raw materials into several different displays; provide skills in post-harvest handling, especially processing catfish into ready-to-eat processed ingredients that are healthy, nutritious, practical and economical; giving creative skills to PKK member mothers and young women in making catfish dragon nuggets and legs and, providing skills in packaging fish processed products (specifically making nuggets and dragon legs). The method used included material debriefing through counseling, practice and demonstration plots, then carried out monitoring and evaluation. During the practical activities carried out mentoring to help the target audience produce good products. The evaluation results show an increase in knowledge, understanding and skills in processing catfish as a new processed product in the form of nuggets and dragon feet that are preferred and beneficial to health and can be used as a business opportunity.
\end{abstract}

Keywords: catfish, food diversification, Kaliwangi Village, nuggets, processing

\title{
1. Pendahuluan
}

Ikan sebagai salah satu sumber protein hewan mempunyai manfaat sangat besar dalam mendukung kesehatan manusia (Morris et al., 2003). Selain sebagai sumber protein, ikan juga mengandung asam lemak omega 3 yang bermanfaat dalam meningkatkan kecerdasan, mencegah pikun dan penyakit jantung (Nurjanah et al., 2015). Sejalan dengan program pemerintah yang telah tertuang dalam Undang-undang Nomor 18 tahun 2012 Pasal 50 ayat 3 tentang Pangan yang menyatakan bahwa Pemerintah dan atau Pemerintah Daerah perlu melakukan promosi penggunaan pangan lokal untuk mendukung terwujudnya kedaulatan, kemandirian dan ketahanan pangan nasional. Dengan demikian maka Kementerian Kelautan dan Perikanan sebagai institusi teknis Pemerintah Pusat yang berperan dalam menangani pangan berbasis ikan berperan aktif di dalam kegiatan sosialisasi peningkatan konsumsi ikan pada masyarakat. Kegiatan tersebut terkenal dengan sebutan GEMARIKAN atau Gerakan memasyarakatkan makan ikan.

Ikan sebagai salah satu sumber bahan pangan yang melimpah di Indonesia, baik ikan laut, payau maupun tawar. Sejalan dengan meningkatnya kesadaran masyarakat terhadap manfaat daging ikan bagi kesehatan tubuh, maka meningkat pula pengembangan usaha budidaya ikan di Indonesia (Syamsunarno \& Sunarno, 2016). Salah satu jenis ikan air tawar yang menjadi komoditas unggulan adalah ikan lele. Ikan perairan tawar tersebut mempunyai beberapa kelebihan antara lain mudah dibudidaya, tingkat mortalitas rendah, laju pertumbuhan lebih tinggi dibandingkan beberapa spesies ikan air tawar lainnya, benih mudah diperoleh dan banyak disukai oleh masyarakat (Sitio et al., 2017). Disamping beberapa hal tersebut, daging lele lebih tebal dibandingkan daging pada ikan air tawar lainnya seperti nila, nilem, mujair dan tawes 
Ikan lele mempunyai kandungan gizi, khususnya protein yang sangat bermanfaat untuk kesehatan (Listyarini et al., 2018). Protein berfungsi untuk pertumbuhan, mengganti jaringan yang rusak dan meningkatkan daya tahan tubuh terhadap serangan penyakit. Selain mengandung protein, ikan lele asam lemak tak jenuh yang bermanfaat untuk menangkal terjadinya serangan jantung (Astiana et al., 2015; Asriani et al., 2019). Berikut ini adalah komposisi gizi yang terkandung dalam daging ikan lele (Tabel 1)

Tabel 1. Komposisi Kandungan Gizi pada Ikan Lele

\begin{tabular}{lc}
\hline Komposisi & Jumlah $(\%)$ \\
\hline Protein & 17,7 \\
Lemak & 4,8 \\
Mineral & 1,2 \\
Karbohidrat & 0,3 \\
Air & 76 \\
\hline Sumber : Vaas 1985 dalam Astawan 2008
\end{tabular}

Sumber: Vaas 1985 dalam Astawan 2008

Protein terkandung asam amino esensial dan non esensial, asam amino esensial adalah asam amino yang dibutuhkan untuk kelangsungan proses biokimiawi yang terjadi di dalam tubuh, sedangkan asam-asam amino tersebut tidak dapat diproduksi oleh tubuh sehingga harus diperoleh dari input nutrisi yang masuk ke dalam tubuh (Astiana et al., 2015). Asam-asam amino yang terkandung dalam protein lele adalah seperti yang tersaji dalam Tabel 2.

Tabel 2. Komposisi Asam amino yang terkandung dalam Protein Ikan Lele

\begin{tabular}{lc}
\hline Asam Amino & Jumlah (\%) \\
\hline Arginin & 6,3 \\
Histidin & 2,8 \\
Isoleusin & 4,3 \\
Leusin & 9,5 \\
Lisin & 10,5 \\
Methionin & 1,4 \\
Fenilalanin & 4,8 \\
Threonin & 4,8 \\
Valin & 4,7 \\
Triptophan & 0,8 \\
\hline Sumber: Astawan 2008 &
\end{tabular}

Sumber: Astawan 2008

Nugget dan kaki naga merupakan dua diantara sekian banyaknya hasil diversifikasi pangan yang telah dikenal oleh sebagian besar masyarakat. Makanan tersebut umumnya berbahan baku daging ayam, yang dibalur dengan tepung roti (modifiet starch). Mengandung protein, lemak, karbohidrat serta kalsium yang diperoleh dari daging ayam, minyak dan tepung roti. Dewasa ini bahan baku makanan tersebut dapat divariasi dengan bahan lain seperti ikan, jamur, tahu, dan tempe. Ikan yang digunakan juga dapat berasal dari ikan laut maupun ikan air tawar. Salah satu jenis ikan air tawar yang dapat digunakan sebagai bahan baku pembuatan nugget adalah ikan lele.

Khalayak sasaran adalah ibu-ibu dan remaja putri yang telah mempunyai ketrampilan dalam melakukan pengolahan ikan. Namun belum mempunyai kemampuan dalam mengolah 
ikan menjadi produk olahan modern. Pada umumnya ikan hanya diolah dalam bentuk olahan tradisional seperti ikan goreng, pepes ikan dan di sayur dengan menambahkan santan atau kecap. Teknik penanganan pasca panen ikan lele yang meliputi teknik pemilihan bahan baku segar, pengolahan hingga pengemasan membutuhkan tingkat ketrampilan dan kreatifitas yang tinggi namun hal tersebut merupakan sesuatu yang cepat dan mudah dimengerti, dipahami dan dilakukan oleh ibu-ibu dan remaja putri yang biasa bekerja di dapur. Oleh karena itu khalayak sasaran dalam kegiatan IPTEKS ini adalah Ibu-ibu dan remaja putri putus sekolah yang tergabung dalam PKK Desa Kaliwang.

Nugget lele dan kaki naga dapat langsung dikonsumsi atau disimpan dalam kondisi beku (frozen) dengan batasan waktu tertentu, antara lain tergantung pada temperatur penyimpanan, kebersihan wadah penyimpanan, proses pemasakan dan bahan baku produk tersebut. Setiap produk olahan mempunyai standar baku untuk menjaga kualitas produk disamping untuk melindungi konsumen dari dampak buruk produk yang berbahaya terhadap keamanan. Standar Nasional Indonesia yang spesifik untuk nugget ikan belum ada. Oleh karena itu, produk nugget lele ini dapat mengacu pada SNI chicken nugget dengan nomor SNI 01- 6683- 2002 (Anonim, 2002). Karakteristik SNI chicken nugget yang menjadi parameter nugget ikan adalah keadaan (aroma, rasa, dan tekstur), kadar air, protein, lemak, dan karbohidrat.

\section{Metode Pendekatan}

Pendekatan metode yang dilakukan dalam kegiatan ini meliputi pembekalan materi melalui penyuluhan/ceramah, praktek dan demostrasi plot (demplot).

1. Pembekalan materi melalui ceramah

Pembekalan materi/informasi secara oral dimaksudkan sebagai manivestasi transfer teknologi kepada khalayak sasaran (Ibu-ibu dan remaja putri di Desa Kaliwangi) berupa teknik penanganan ikan lele pasca pemanenan hingga pengemasan. Materi ceramah meliputi : teknik pemilihan bahan baku yang berkualitas (ikan yang segar) sesuai standar mutu, teknik penyiangan dan pembersihan ikan lele sebagai bahan baku utama, persiapan bumbu, pembuatan surimi dan pencampuran adonan sesuai jenis produk yang akan dihasilkan, pembentukan atau pencetakan, pemasakan/penggorengan, dan pengemasan produk. Selanjutnya teknik penyimpanan dalam keadaan beku (frozen).

2. Praktek.

Kegiatan praktek dimaksudkan untuk meningkatkan pemahaman materi dan ketrampilan khalayak sasaran secara nyata untuk menumbuhkan kreatifitas dan kemauan belajar serta menggali ide-ide untuk mengoptimalkan potensi bahan baku lokal yang tersedia di Desa Kaliwangi. Disamping itu juga dilakukan untuk menanggulangi/mencarikan solusi pemecahan masalah yang dihadapi dalam pelaksanakan kegiatan penanganan pasca panen ikan air tawar.

Materi praktek meliputi tata cara persiapan bahan mentah (ikan lele segar), bumbubumbu pelengkap dan peralatan pendukung, pembuatan filet, pencucian, pembuatan produk (nugget dan kaki naga), dan teknik pengemasan, serta teknik penyimpanan. Keseluruhan kegiatan seperti tersaji dalam Gambar 1.

3. Diskusi dan evaluasi.

Selama proses transfer teknologi diselenggarakan sesi diskusi dan tanya jawab yang dilakukan pada saat penyampaian materi secara langsung (oral) dan praktek dengan tujuan memperjelas materi yang disampaikan. 


\section{Demonstrasi Plot}

Demonstrasi plot yang dilakukan meliputi:

a. Teknik pemilihan bahan baku (ikan segar) sesuai standar mutu,

b. Cara Penyiangan (pembuangan bagian tubuh ikan yang menjadi sumber berkembangnya bakteri)

c. Cara pencucian ikan yang benar

d. Pengelupasan daging ikan (membuat fillet)

e. Teknik pembuatan bahan baku (daging lele halus yang telah diblender dan dikukus)

f. Persiapan bumbu (bawang putih, garam, merica), telur, tepung panir, tepung terigu dan sayuran

g. Teknik pengolahan lanjutan sesuai jenis produk (nugget dan kaki naga)

h. Teknik pemasakan/pematangan produk (digoreng, dikukus)

i. Teknik penyajian

j. Teknik pengemasan produk matang dan beku.
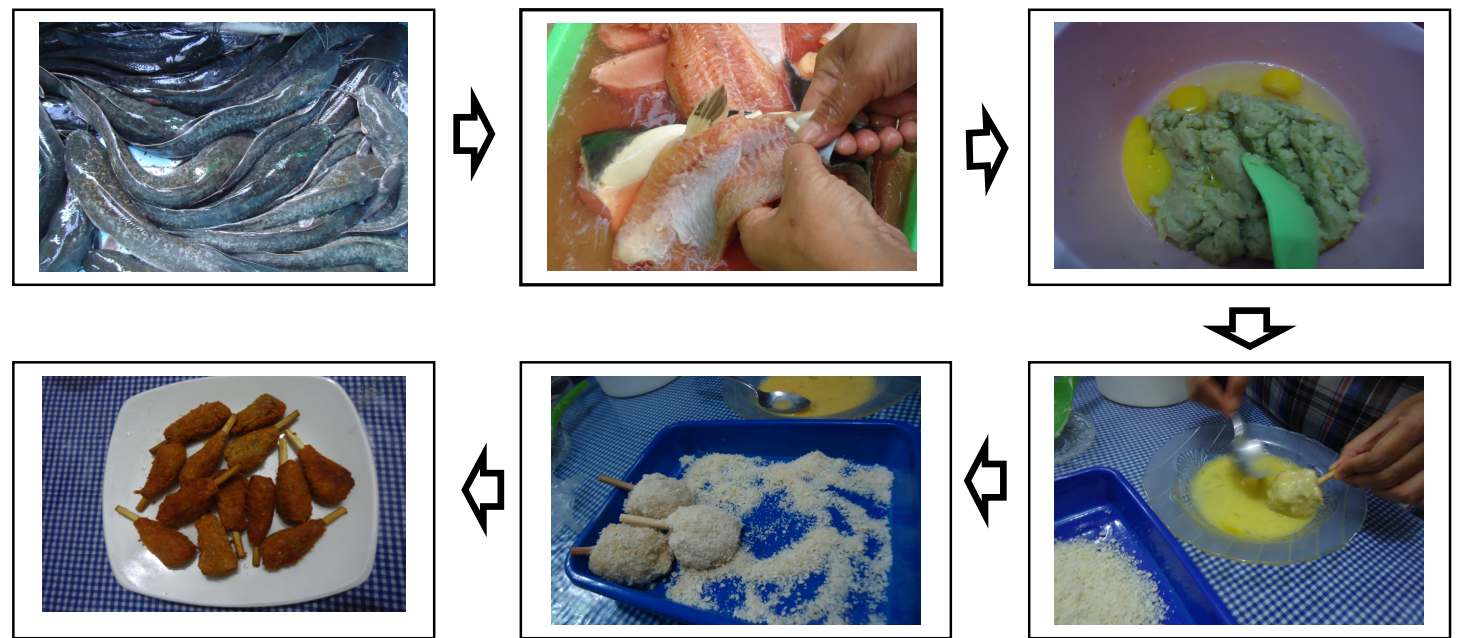

Gambar 1. Urutan kegiatan praktek 


\section{Hasil dan Pembahasan}

Berdasarkan hasil kegiatan yang telah kami laksanakan di Desa Kaliwangi Kecamatan Purwojati Kabupaten Banyumas tepatnya pada kelompok PKK RT-3 dan RT-4 RW-2 telah menghasilkan suatu jenis makanan baru yang berprotein tinggi yaitu nugget dan kaki naga ikan. Hal ini merupakan salah satu upaya diversivikasi pengolahan makanan berbahan baku ikan lele. Desa Kaliwangi tepatnya di RT-3 dan RT-4 RW-2 banyak masyarakat yang memanfaatkan pekarangan sebagai lahan budidaya ikan lele. Pengolahan ikan lele menjadi nugget dan kaki naga membuka peluang bagi masyarakat khususnya di Desa Kaliwangi untuk membuka usaha pengolahan makanan berbahan baku ikan lele. Tersedianya ikan lele disekitar lokasi usaha akan meminimalisir biaya produksi sehingga dapat diperoleh keuntungan lebih besar.

Ikan lele yang berprotein tinggi tersebut tidak hanya dapat dimanfaatkan sebagai sumber pendapatan/usaha keluarga, tetapi juga dapat digunakan sebagai upaya untuk meningkatkan gizi keluarga. Bentuk nugget dan kaki naga yang menarik, serta rasanya yang gurih akan menarik minat anak-anak untuk mengkonsumsi makanan sehat tersebut.

Selama kegiatan tersebut berlangsung, hampir semua peserta aktif terlibat dimulai dari kegiatan penyuluhan, praktek dan demplot. Pada saat kegiatan penyuluhan sebagian besar peserta aktif bertanya dan kegiatan diskusi berlangsung dengan baik. Sedangkan selama praktek dan demplot, semua peserta yang menyukai kegiatan memasak dan menyukai ikan air tawar secara aktif terlibat didalam mengolah makanan tersebut sampai selesai. Walaupun ada beberapa peserta yang kurang menyukai bau amis ikan lele, tetapi aroma khas ikan air tawar tersebut dapat diminimalisir menggunakan air perasan jeruk nipis atau buah nanas. Pembentukan naget dilakukan menggunakan beberapa cara antara lain menggunakan cetakan berbentuk angka dan huruf, ikan, bulat dan oval. Selain itu sebagian juga dibentuk secara manual dengan menempelkan bahan pada stik es krim, sehingga berbentuk seperti es krim. Hasil olahan naget dan kaki naga tersebut, sebagian dibagikan secara gratis dan sebagian lagi dijual dengan harga Rp. 7.500 per kemasan yang berisi 10 buah naget berbagai bentuk, yang dikemas dalam plastik kemasan yang diberi label sederhana. Tujuan penjualan hasil olahan tersebut sebagai salah satu upaya orientasi pasar terhadap produk olahan tersebut di Desa Kaliwangi dan sekitarnya. Hal tersebut dapat digunakan sebagai dasar perhitungan dalam analisis hasil usaha.

Evaluasi yang dilaksanakan untuk mengetahui adanya perubahan pengetahuan, kemampuan, ketrampilan dan perilaku khalayak sasaran meliputi evaluasi teori atau pengetahuan tentang ikan lele, kandungan nutrisi dan manfaatnya bagi kesehatan, penanganan pasca panen yang meliputi cara penyiangan/pembersihan, pengawetan menggunakan bahan organik dan teknik penyimpanan yang benar sehingga tidak merusak nilai gizi, teknik pembekuan, pengolahan menjadi beberapa produk yang mempunyai nilai jual (nugget dan kaki naga), serta pengemasan produk yang dilakukan secara lisan dan tertulis. Evaluasi secara lisan dilakukan pada saat ceramah/penyuluhan dengan cara tanya jawab secara langsung. Sedangkan evaluasi secara tertulis dilakukan menggunakan lembar evaluasi yang terdiri dari beberapa pertanyaan yang terkait materi penyuluhan. Evaluasi ketrampilan dilakukan pada saat praktek langsung, untuk mengetahui peningkatan kemampuan dan ketrampilan khalayak sasaran. Evaluasi dilakukan pada saat praktek pembuatan kaki naga dan nugget. Mulai dari teknik pemilihan ikan yang segar, teknik penyiangan/pembersihan dari kulit dan duri (membuat fillet), kelengkapan bumbu dan teknik meramu bumbu dengan bahan baku yang telah dihancurkan, pencetakan/pembentukan produk, dan pemasakan/penggorengan. Selanjutnya evaluasi dilakukan juga pada cara pengemasan yang higienis dan menarik, sehingga memancing minat konsumen 
untuk membeli produk tersebut. Evaluasi dampak dilakukan sebagai indikator telah terjadinya perubahan perilaku dan sikap khalayak sasaran, khususnya dalam cara pandang terhadap bahan baku lokal yang umumnya hanya dijual dalam bentuk hidup atau segar, menjadi suatu produk olahan daging yang lebih variatif, bergizi dan bermanfaat untuk pengobatan suatu penyakit tertentu, serta dapat meningkatkan pendapatan keluarga.

Berdasarkan hasil pengamatan dan evaluasi selama kurang lebih dua bulan, menunjukkan adanya respon positif dari para peserta yang selanjutnya ditularkan pada warga yang lainnya. Sebagian warga menjadi lebih memahami manfaat gizi ikan untuk meningkatkan kecerdasan anak-anak, perlunya variasi olahan ikan untuk menumbuhkan selera makan bagi anggota keluarga serta peningkatan ketrampilan dalam mengolah ikan lele menjadi bentuk makanan olahan yang lebih menarik, tetap bergizi dan murah. Selain itu, kegiatan penerapan IPTEKS yang dilakukan di Desa Kaliwangi Kecamatan Purwojati Kabupaten Banyumas tersebut juga telah membuka wawasan beberapa peserta untuk mengembangkan usaha skala rumah tangga dalam pengolahan ikan lele, yang bahan bakunya telah tersedia banyak dilingkungan sekitar sehingga akan lebih meminimalisir biaya produksi.

\section{Kesimpulan dan Saran}

\section{Kesimpulan}

Hasil evaluasi menunjukkan adanya peningkatan pengetahuan, pemahaman dan ketrampilan khalayak sasaran dalam penanganan pasca panen ikan lele sebagai produk olahan baru berupa nugget dan kaki naga yang disukai dan bergizi serta dapat digunakan sebagai salah satu peluang usaha.

\section{Saran}

Perlu adanya stimulus dan motivasi yang berkelanjutan terhadap masyarakat khususnya ibu-ibu dan remaja putri di Desa Kaliwangi untuk ikut mengembangkan perekonomian Desa melalui usaha skala rumah tangga baik dibidang makanan olahan maupun bahan baku (ikan segar), untuk menurunkan migrasi penduduk desa ke kota besar maupun sebagai tenaga kerja ke luar negeri.

\section{DAFTAR PUSTAKA}

Anonim. 2011. Materi Penyuluhan Ikan Lele. Pusat Penyuluhan Perikanan dan Kelautan.

Asriani, A., Santoso, J., Listyarini, S. 2019. Nilai Gizi Konsentrat Protein Ikan Lele Dumbo (Clarias gariepenus) Ukuran Jumbo. Jurnal Kelautan dan Perikanan Terapan (JKPT), 1(2), 77-86.

Astawan M. 2004. Manfaat Ikan Bagi Jantung Dan Wajah, http://www.dkp.go.id, diakses tanggal 04 September 2008

Astiana, I., Suwandi, R., Suryani, A. A., Hidayat, T. 2015. Pengaruh penggorengan belut sawah (Monopterus albus) terhadap komposisi asam amino, asam lemak, kolesterol dan mineral. DEPIK Jurnal Ilmu-Ilmu Perairan, Pesisir dan Perikanan, 4(1).

Irianto K. 2004. Gizi dan Pola Hidup Sehat, CV Yrama Widya

Khumaidi, M. 1994. Gizi Masyarakat, Penerbit BPK Gunung Mulia, Jakarta. 
Lestari, A.P. 2012. Pengaruh substitusi ikan lele (Clarias batrachus) dengan wortel (Daucus carota L) terhadap nilai organoleptik dan nilai zat gizi pada pembuatan nugget. Skripsi Program Studi Ilmu Gizi Fakultas Ilmu-ilmu Kesehatan Universitas Esa Unggul.

Listyarini, S., Asriani, A., Santoso, J. 2018. Konsentrat Protein Ikan Lele Dumbo (Clarias gariepenus) Afkir Dalam Kerupuk Melarat Untuk Mencapai Sustainable Development Goals. Jurnal Matematika Sains dan Teknologi, 19(2), 106-113.

Machmud, N.F., N. Kurniawati., K. Haetami. 2012. Pengkayaan Protein dari Surimi Lele Dumbo Pada Brownies Terhadap Tingkat Kesukaan. Jurnal Perikanan dan Kelautan.

Morris, M. C., Evans, D. A., Bienias, J. L., Tangney, C. C., Bennett, D. A., Wilson, R. S., Schneider, J. 2003. Consumption of Fish and n-3 Fatty Acids and Risk of Incident Alzheimer Disease. Arch Neurol, 60, 940-946.

Nurjanah, Hidayat. T., Perdana, S. 2015. Analisis faktor-faktor yang mempengaruhi konsumsi ikan pada wanita dewasa di Indonesia. JPHPI, 18(1), 19-27.

Sitio, M. H. F., Jubaedah, D., Syaifudin, M. 2017. Kelangsungan Hidup dan Pertumbuhan Benih Ikan Lele (Clarias sp.) Pada Salinitas Media yang Berbeda. Jurnal Akuakultur Rawa Indonesia, 5(1), 83-96.

Syamsunarno, M. B., Sunarno, M. T. 2016. Budidaya Ikan Air Tawar Ramah Lingkungan Untuk Mendukung Keberlanjutan Penyediaan Ikan Bagi Masyarakat. In Seminar Nasional Perikanan dan Kelautan 2016.

Wijayanti, I., dan J. Santoso., A.M Jacoeb. 2012. Pengaruh frekuensi pencucian Terhadap Karakteristik Gel Surimi Lele Dumbo 8 (1): 32 - 38. 